\title{
Bimbingan dan Konseling Sekolah
}

\author{
H. Kamaluddin \\ Email: pps.uhamka@yahoo.co.id, Universitas Muhammadiyah Prof. Dr. HAMKA
}

\begin{abstract}
Abstrak: Penyuluh memainkan peranan penting dalam sistem pendidikan dan mereka dianggap sebagai psikolog sekolah. Penyuluhan harus mencangkup dan mempunyai sasaran untuk mengembangkan serta memperluas potensi-potensi siswa. Mereka harus memiliki kemampuan hubungan masyarakat hubungan masyarakat yang bagus dan solusi alternative kepada para siswa. Penyuluh melaksanakan perencanaan, menjalankan program, pengawasan dan evaluasi serta melaksanakan tindak lanjut dalam kegiatan penyuluhan. Penyuluhan juga bertanggung jawab dalam menginformasikan jalur-jalur karir kepada para siswa. Penyuluhan bertindak sebagai penyelesaian masalah solver para siswa. Menteri Pendidikan telah memberikan kebebasan penuh kepada penyuluhan untuk mengembangkan potensi siswa dan menyediakan bimbingan serta penyuluhan yang efektif.
\end{abstract}

Kata kunci: bimbingan dan konseling sekolah

Abstract: The counselor plays an important role in the education system. They are regarded as school psychology. Counseling must possess and target to expand and develop the student's potentials. They must posses good public relations and alternative solutions to students. The counselor conducts planning, carry out the programme, monitor and evaluate, and take further actions in their counseling activities. The counselor is also responsible to provide career path to the students. To conclude, the counselor act as a problem solver to the students. The Ministry of Education has given full freedom to the counselor to develop the students' potentials and provide effective guidance and counseling.

Key words: school counceling and guidance

\section{Pendahuluan}

Pelayanan bimbingan dan konseling di sekolah merupakan usaha membantu peserta didik dalam pengembangan kehidupan pribadi, kehidupan sosial, kegiatan belajar, serta perencanaan dan pengembangan karir. Pelayanan bimbingan dan konseling memfasilitasi pengembangan peserta didik secara individual, kelompok, dan atau klasikal, sesuai dengan kebutuhan, potensi, bakat, minat, perkembangan, kondisi, serta peluang-peluang yang dimiliki. Pelayanan ini juga membantu mengatasi kelemahan dan hambatan serta masalah yang dihadapi peserta didik.

Dasar pemikiran penyelenggaraan bimbingan dan konseling di sekolah bukan semata-mata terletak pada ada atau tidak adanya landasan hukum (perundang-undangan) atau ketentuan dari atas, namun yang lebih penting adalah menyangkut upaya memfasilitasi peserta didik yang selanjutnya disebut konseli, agar mampu mengembangkan petensi dirinya atau mencapai tugas-tugas perkembangannya (menyangkut aspek fisik, emosi, intelektual, sosial dan moralspiritual).

Konseling sebagai seorang individu yang sedang berada dalam proses berkembang atau menjadi (on becoming), yaitu berkembang ke arah kematangan atau kemandirian. Untuk mencapai kematangan tersebut, konseli memerlukan bimbingan karena mereka masih kurang memiliki pemahaman atau wawasan tentang dirinya dan lingkungannya, juga pengalaman yang menentukan arah kehidupannya. Di samping itu, terdapat suatu keniscayaan bahwa proses perkembangan konseli tidak selalu berlangsung secara mulus, atau bebas dari masalah. Dengan kata lain, proses perkembangan itu tidak selalu berjalan dalam alur linier, lurus, atau searah dengan potensi, harapan, dan nilai-nilai yang dianut.

Permasalahan layanan bimbingan dan konseling di sekolah antara lain 1) Bagaimanakah peran bimbingan dan konseling di sekolah? dan 2) Bagaimana cara meningkatkan mutu layanan bimbingan dan konseling di sekolah? 
Berdasarkan rumusan masalah yang sudah dikemukakan di atas, maka tujuan kajian ini yaitu mendapatkan data dan informasi tentang: 1) bagaimana peranan bimbingan dan konseling di sekolah; dan 2) bagaimana cara meningkatkan mutu layanan bimbingan dan konseling di sekolah.

Tujuan penulisan ini yaitu mensosialisasikan penyuluhan bimbingan dan konseling sekolah.

\section{Kajian Literatur}

\section{Pengertian Bimbingan dan Konseling}

Menurut Prayitno (2004), bimbingan dan konseling adalah pelayanan bantuan untuk peserta didik, baik secara perorangan maupun kelompok agar mandiri dan bisa berkembang secara optimal, dalam bimbingan pribadi, sosial, belajar maupun karier melalui berbagai jenis layanan dan kegiatan pendukung berdaarkan norma-norma yang berlaku.

Bimbingan dan konseling merupakan upaya proaktif dan sistematik dalam memfasilitasi individu mencapai tingkat perkembangan yang optimal, pengembangan perilaku yang efektif, pengembangan lingkungan, dan peningkatan fungsi atau manfaat individu dalam lingkungannya. Semua perubahan perilaku tersebut merupakan proses perkembangan individu, yakni proses interaksi antara individu dengan lingkungan melalui interaksi yang sehat dan produktif. Bimbingan dan konseling memegang tugas dan tanggung jawab yang penting untuk mengembangkan lingkungan, membangun interaksi dinamis antara individu dengan lingkungan, membelajarkan individu untuk mengembangkan, merubah dan memperbaiki perilaku.

Bimbingan dan konseling bukanlah kegiatan pembelajaran dalam konteks adegan mengajar yang layaknya dilakukan guru sebagai pembelajaran bidang studi, melainkan layanan ahli dalam konteks memandirikan peserta didik. (ABKIN, 2007).

Oleh karena itu, bimbingan dan konseling merupakan layanan ahli oleh konselor (guru bimbingan dan konseling). Konselor adalah salah satu kualifikasi pendidikan, yaitu tenaga kependidikan, yaitu tenaga kependidikan yang memiliki kekhususan pada bidang bimbingan dan konseling, yang berpartisipasi dalam menyelenggarakan pendidikan.

\section{Fungsi, Prinsip dan Asas Bimbingan dan Konseling}

Layanan bimbingan dan konseling di sekolah memiliki peran yang sangat penting. Oleh karena itu, sebelum kita membahas lebih jauh alangkah baiknya kita mengetahui fungsi, prinsip, dan asas bimbingan dan konseling.

\section{Fungsi Bimbingan dan Konseling}

Uman Suherman yang dikutip oleh Sudrajat (2008) mengemukakan sepuluh fungsi bimbingan dan konseling, yaitu: 1) Fungsi Pemahaman, yaitu fungsi bimbingan dan konseling membantu konseli agar memiliki pemahaman terhadap dirinya (potensinya) dan lingkungannya (pendidikan, pekerjaan, dan norma agama). Berdasarkan pemahaman ini, konseli diharapkan mampu mengembangkan potensi dirinya secara optimal, dan menyesuaikan dirinya dengan lingkungan secara dinamis dan konstruktif; 2) Fungsi Preventif, yaitu fungsi yang berkaitan dengan upaya konselor untuk senantiasa mengantisipasi berbagai masalah yang mungkin terjadi dan berupaya untuk mencegahnya, supaya tidak dialami oleh konseli. Melalui fungsi ini, konselor memberikan bimbingan kepada konseli tentang cara menghindarkan diri dari perbuatan atau kegiatan yang membahayakan dirinya. Adapun teknik yang dapat digunakan adalah pelayanan orientasi, informasi, dan bimbingan kelompok. Beberapa masalah yang perlu diinformasikan kepada para konseli dalam rangka mencegah terjadinya tingkah laku yang tidak diharapkan, diantaranya: bahayanya minuman keras, merokok, penyalahgunaan obat-obatan, drop out, dan pergaulan bebas (free sex); 3) Fungsi Pengembangan, yaitu fungsi bimbingan dan konseling yang sifatnya lebih proaktif dari fungsifungsi lainnya. Konselor senantiasa berupaya untuk menciptakan lingkungan belajar yang kondusif, yang memfasilitasi perkembangan konseli. Konselor dan personel Sekolah/Madrasah lainnya secara sinergi sebagai teamwork berkolaborasi atau bekerjasama merencanakan dan melaksanakan program bimbingan secara sistematis dan berkesinambungan dalam upaya 
membantu konseli mencapai tugas-tugas perkembangannya. Teknik bimbingan yang dapat digunakan disini adalah pelayanan informasi, tutorial, diskusi kelompok atau curah pendapat (brain storming), home room, dan karyawisata; 4) Fungsi Penyembuhan, yaitu fungsi bimbingan dan konseling yang bersifat kuratif. Fungsi ini berkaitan erat dengan upaya pemberian bantuan kepada konseli yang telah mengalami masalah, baik menyangkut aspek pribadi, sosial, belajar, maupun karir. Teknik yang dapat digunakan adalah konseling, dan remedial teaching; 5) Fungsi Penyaluran, yaitu fungsi bimbingan dan konseling dalam membantu konseli memilih kegiatan ekstrakurikuler, jurusan atau program studi, dan memantapkan penguasaan karir atau jabatan yang sesuai dengan minat, bakat, keahlian dan ciri-ciri kepribadian lainnya. Dalam melaksanakan fungsi ini, konselor perlu bekerja sama dengan pendidik lainnya di dalam maupun di luar lembaga pendidikan; 6) Fungsi Adaptasi, yaitu fungsi membantu para pelaksana pendidikan, kepala Sekolah/Madrasah dan staf, konselor, dan guru untuk menyesuaikan program pendidikan terhadap latar belakang pendidikan, minat, kemampuan, dan kebutuhan konseli. Dengan menggunakan informasi yang memadai mengenai konseli, pembimbing/konselor dapat membantu para guru dalam memperlakukan konseli secara tepat, baik dalam memilih dan menyusun materi Sekolah/Madrasah, memilih metode dan proses pembelajaran, maupun menyusun bahan pelajaran sesuai dengan kemampuan dan kecepatan konseling; 7) Fungsi Penyesuaian, yaitu fungsi bimbingan dan konseling dalam membantu konseli agar dapat menyesuaikan diri dengan diri dan lingkungannya secara dinamis dan konstruktif; 8) Fungsi Perbaikan, yaitu fungsi bimbingan dan konseling untuk membantu konseli sehingga dapat memperbaiki kekeliruan dalam berfikir, berperasaan dan bertindak (berkehendak). Konselor melakukan intervensi (memberikan perlakuan) terhadap konseli supaya memiliki pola berfikir yang sehat, rasional dan memiliki perasaan yang tepat sehingga dapat mengantarkan mereka kepada tindakan atau kehendak yang produktif dan normatif; 9) Fungsi Fasilitasi, memberikan kemudahan kepada konseli dalam mencapai pertumbuhan dan perkembangan yang optimal, serasi, selaras dan seimbang seluruh aspek dalam diri konseli; dan 10) Fungsi Pemeliharaan, yaitu fungsi bimbingan dan konseling untuk membantu konseli supaya dapat menjaga diri dan mempertahankan situasi kondusif yang telah tercipta dalam dirinya. Fungsi ini memfasilitasi konseli agar terhindar dari kondisi-kondisi yang akan menyebabkan penurunan produktivitas diri. Pelaksanaan fungsi ini diwujudkan melalui program-program yang menarik, rekreatif dan fakultatif (pilihan) sesuai dengan minat konseli.

Fungsi yang dikemukakan di atas dapat di singkat sebagai berikut: 1) Fungsi pemahaman, yaitu fungsi membantu peserta memahami diri dan lingkungan; 2) Fungsi Pencegahan, yaitu fungsi untuk membantu peserta didik mampu mencegah atau menghindari diri dari berbagai permasalahan yang dapat menghambat perkembangan dirinya; 3) Fungsi Pengentasan, yaitu fungsi untuk membantu peserta didik mengatasi masalah yang didalamnya; 4) Fungsi Pemeliharaan dan Pengembangan, yaitu fungsi untuk membantu peserta didik memlihara dan menumbuhkembangkan berbagai potensi dan kondisi positif yang dimilikinya; 5) Fungsi Advokasi, yaitu fungsi untuk membantu peserta didik memperoleh pembelaan atas hak dan atau kepentingannya yang kurang mendapat perhatian.

\section{Prinsip Bimbingan dan Konseling}

Terdapat beberapa prinsip dasar yang dipandang sebagai pondasi atau landasan bagi pelayanan bimbingan dan konseling. Prinsip-prinsip ini berasal dari konsep-konsep filosofis tentang kemanusiaan yang menjadi dasar bagi pemberian pelayanan bantuan atau bimbingan, baik di Sekolah/Madrasah maupun di luar Sekolah/ Madrasah.

Prinsip-prinsip tersebut yaitu bimbingan dan konseling: 1) diperuntukkan bagi semua konseling. Prinsip ini berarti bahwa bimbingan diberikan kepada semua konseli atau konseli, baik yang tidak bermasalah maupun yang bermasalah; baik pria maupun wanita; baik anak-anak, remaja, maupun dewasa. Dalam hal ini pendekatan yang digunakan dalam bimbingan lebih bersifat preventif dan pengembangan dari pada penyembuhan (kuratif); dan lebih diutamakan teknik kelompok dari pada perseorangan 
(individual); 2) sebagai proses individuasi. Setiap konseli bersifat unik (berbeda satu sama lainnya), dan melalui bimbingan konseli dibantu untuk memaksimalkan perkembangan keunikannya tersebut. Prinsip ini juga berarti bahwa yang menjadi fokus sasaran bantuan adalah konseli, meskipun pelayanan bimbingannya menggunakan teknik kelompok; 3) menekankan hal yang positif. Dalam kenyataan masih ada konseli yang memiliki persepsi yang negatif terhadap bimbingan, karena bimbingan dipandang sebagai satu cara yang menekan aspirasi. Sangat berbeda dengan pandangan tersebut, bimbingan sebenarnya merupakan proses bantuan yang menekankan kekuatan dan kesuksesan, karena bimbingan merupakan cara untuk membangun pandangan yang positif terhadap diri sendiri, memberikan dorongan, dan peluang untuk berkembang; 4) merupakan Usaha Bersama. Bimbingan bukan hanya tugas atau tanggung jawab konselor, tetapi juga tugas guru-guru dan kepala Sekolah/ Madrasah sesuai dengan tugas dan peran masingmasing. Mereka bekerja sebagai teamwork; 5) pengambilan keputusan merupakan hal yang esensial dalam bimbingan dan konseling. bimbingan diarahkan untuk membantu konseli agar dapat melakukan pilihan dan mengambil keputusan. Bimbingan mempunyai peranan untuk memberikan informasi dan nasihat kepada konseli, yang itu semua sangat penting baginya dalam mengambil keputusan. Kehidupan konseli diarahkan oleh tujuannya, dan bimbingan memfasilitasi konseli untuk mempertimbangkan, menyesuaikan diri, dan menyempurnakan tujuan melalui pengambilan keputusan yang tepat. Kemampuan untuk membuat pilihan secara tepat bukan kemampuan bawaan, tetapi kemampuan yang harus dikembangkan. Tujuan utama bimbingan adalah mengembangkan kemampuan konseli untuk memecahkan masalahnya dan mengambil keputusan; 5) berlangsung dalam Berbagai Setting (adegan) Kehidupan. Pemberian pelayanan bimbingan tidak hanya berlangsung di Sekolah/ Madrasah, tetapi juga di lingkungan keluarga, perusahaan/industri, lembaga-lembaga pemerintah/swasta, dan masyarakat pada umumnya. Bidang pelayanan bimbingan pun bersifat multi aspek, yaitu meliputi aspek pribadi, sosial, pendidikan, dan pekerjaan.
Prinsip-prinsip di atas dapat digambarkan sebagai berikut.

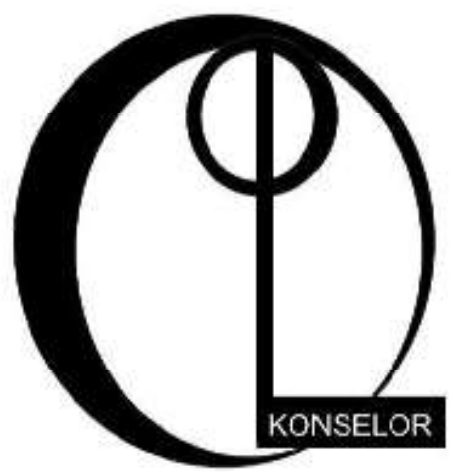

\section{Asas Bimbingan dan Konseling}

Keterlaksanaan dan keberhasilan pelayanan bimbingan dan konseling sangat ditentukan oleh diwujudkannya asas-asas berikut, yaitu:

Pertama, Asas kerahasiaan, yaitu asas bimbingan dan konseling yang menuntut dirahasiakanya segenap data dan keterangan tentang konseli (konseli) yang menjadi sasaran pelayanan, yaitu data atau keterangan yang tidak boleh dan tidak layak diketahui oleh orang lain. Dalam hal ini guru pembimbing berkewajiban penuh memelihara dan menjaga semua data dan keterangan itu sehingga kerahasiaanya benarbenar terjamin. Kedua, Asas kesukarelaan, yaitu asas bimbingan dan konseling yang menghendaki adanya kesukaan dan kerelaan konseli (konseli) mengikuti/menjalani pelayanan/kegiatan yang diperlukan baginya. Dalam hal ini guru pembimbing berkewajiban membina dan mengembangkan kesukarelaan tersebut. Ketiga, Asas keterbukaan, yaitu asas bimbingan dan konseling yang menghendaki agar konseli (konseli) yang menjadi sasaran pelayanan/kegiatan bersifat terbuka dan tidak berpura-pura, baik di dalam memberikan keterangan tentang dirinya sendiri maupun dalam menerima berbagai informasi dan materi dari luar yang berguna bagi pengembangan dirinya. Dalam hal ini guru pembimbing berkewajiban mengembangkan keterbukaan konseli (konseli). Keterbukaan ini amat terkait pada terselenggaranya asas kerahasiaan dan adanya kesukarelaan pada diri konseli yang menjadi sasaran pelayanan/ kegiatan. Agar konseli dapat terbuka, guru pembimbing terlebih dahulu harus bersikap terbuka dan tidak berpura-pura. Keempat, Asas kegiatan, yaitu asas bimbingan dan konseling 
yang menghendaki agar konseli (konseli) yang menjadi sasaran pelayanan berpartisipasi secara aktif di dalam penyelenggaraan pelayanan/ kegiatan bimbingan. Dalam hal ini guru pembimbing perlu mendorong konseli untuk aktif dalam setiap pelayanan/kegiatan bimbingan dan konseling yang diperuntukan baginya. Kelima, Asas kemandirian, yaitu asas bimbingan dan konseling yang menunjuk pada tujuan umum bimbingan dan konseling, yakni: konseli (konseli) sebagai sasaran pelayanan bimbingan dan konseling diharapkan menjadi konseli-konseli yang mandiri dengan ciriciri mengenal dan menerima diri sendiri dan lingkungannya, mampu mengambil keputusan, mengarahkan serta mewujudkan diri sendiri. Guru pembimbing hendaknya mampu mengarahkan segenap pelayanan bimbingan dan konseling yang diselenggarakannya bagi berkembangnya kemandirian konseli. Keenam, Asas Kekinian yaitu asas bimbingan dan konseling yang menghendaki agar objek sasaran pelayanan bimbingan dan konseling ialah permasalahan konseli (konseli) dalam kondisinya sekarang. Pelayanan yang berkenaan dengan "masa depan atau kondisi masa lampau pun" dilihat dampak dan/atau kaitannya dengan kondisi yang ada dan apa yang diperbuat sekarang. Ketujuh, Asas Kedinamisan yaitu asas bimbingan dan konseling yang menghendaki agar isi pelayanan terhadap sasaran pelayanan (konseli) yang sama kehendaknya selalu bergerak maju, tidak monoton, dan terus berkembang serta berkelanjutan sesuai dengan kebutuhan dan tahap perkembangannya dari waktu ke waktu. Kedelapan, Asas Keterpaduan, yaitu asas bimbingan dan konseling yang menghendaki agar berbagai pelayanan dan kegiatan bimbingan dan konseling, baik yang dilakukan oleh guru pembimbing maupun pihak lain, saling menunjang, harmonis, dan terpadu. Untuk ini kerja sama antara guru pembimbing dan pihak-pihak yang berperan dalam penyelenggaraan pelayanan bimbingan dan konseling perlu terus dikembangkan. Koordinasi segenap pelayanan/kegiatan bimbingan dan konseling itu harus dilaksanakan dengan sebaik-baiknya. Kesembilan, Asas Keharmonisan, yaitu asas bimbingan dan konseling yang menghendaki agar segenap pelayanan dan kegiatan bimbingan dan konseling didasarkan pada dan tidak boleh bertentangan dengan nilai dan norma yang ada, yaitu nilai dan norma agama, hukum dan peraturan, adat istiadat, ilmu pengetahuan, dan kebiasaan yang berlaku. Bukanlah pelayanan atau kegiatan bimbingan dan konseling yang dapat dipertanggungjawabkan apabila isi dan pelaksanaannya tidak berdasarkan nilai dan norma yang dimaksudkan itu. Lebih jauh, pelayanan dan kegiatan bimbingan dan konseling justru harus dapat meningkatkan kemampuan konseli (konseli) memahami, menghayati, dan mengamalkan nilai dan norma tersebut. Kesepuluh, Asas Keahlian yaitu asas bimbingan dan konseling yang menghendaki agar pelayanan dan kegiatan bimbingan dan konseling diselenggarakan atas dasar kaidah-kaidah profesional. Dalam hal ini, para pelaksana pelayanan dan kegiatan bimbingan dan konseling hendaklah tenaga yang benar-benar ahli dalam bidang bimbingan dan konseling. Keprofesionalan guru pembimbing harus terwujud baik dalam penyelenggaraan jenis-jenis pelayanan dan kegiatan dan konseling maupun dalam penegakan kode etik bimbingan dan konseling. Kesebelas, Asas Alih Tangan Kasus yaitu asas bimbingan dan konseling yang menghendaki agar pihak-pihak yang tidak mampu menyelenggarakan pelayanan bimbingan dan konseling secara tepat dan tuntas atas suatu permasalahan konseli (konseli) mengalihtangankan permasalahan itu kepada pihak yang lebih ahli. Guru pembimbing dapat menerima alih tangan kasus dari orang tua, guru-guru lain, atau ahli lain; dan demikian pula guru pembimbing dapat mengalihtangankan kasus kepada guru mata pelajaran/praktik dan lain-lain.

\section{Aspek Yuridis Eksistensi Konselor}

Keberadaan konselor dalam sistem pendidikan nasional dinyatakan sebagai salah satu kualifikasi pendidikan yang sejajar dengan kualifikasi Guru, Dosen, Pamong dan Tutor berdasarkan UndangUndang Nomor 20 tahun 2003, Pasal 1 ayat (6). Pengakuan secara eksplisit dan kesejajaran posisi antara kualifikasi tenaga pendidikan satu dengan yang lainnya mengandung arti bahwa setiap tenaga pendidik, termasuk Konselor, memiliki keunikan konteks dalam tugas, eksplektasi kinerja, dan setting layanan.

Peraturan Menteri Pendidikan Nasional Nomor 
22 tahun 2006, tidak secara eksplisit memposisikan bimbingan dan konseling dalam struktur program pendidikan. Ketidakjelasan konteks dalam tugas dan ekspektasi kinerja konselor bimbingan dan konseling melalui proses pembelajaran yang berpayung pada standar isi. Muncul gejala "Intervasi" profesi sejenis (sebut psikologi sekolah) ke dalam konteks tugas dan kinerja konselor Penegasan Eksistensi Profesi.

Secara Yuridis berbagai peraturan yang ada menguatkan kenyataan bahwa konteks tugas dan Ekspektasi kinerja yang telah dispesifikasikan secara tegas dan eksplisit adalah konteks tugas dan ekspektasi kinerja guru sebagai agen pembelajaran, yang menggunakan bidang studi sebagai konteks layanan, dan tidak mengandung konteks tugas dan Ekspektasi kinerja konselor.

Selanjutnya, ABKIN (2007) mengemukakan praktik bimbingan dan konseling dalam merencanakan, melaksanakan, menilai, dan menindaklanjuti kegiatan pelayanan konseling, sebagai berikut.

\section{Praktik BK oleh Konselor}

Merencanakan, Melaksanakan, Menilai dan Menindaklanjuti Kegiatan Pelayan Konseling terdiri atas: 1) 4 bidang layanan (pribadi, sosial, belajar karier), 2) fungsi layanan (pencegahan, pemahamanan, pemeliharaan dan advokasi), 3) 9 jenis layanan (orientasi, informasi, penguasaan konten, penempatan dan peyalur-an konseling perorangan, bimbingan kelompok konseling, kelompok mediasi dan konsultasi), 4) 6 kegiatan pendukung (aplikasi instrumentasi data, himpunan data, konferensi kasus, tampilan kepustakaan kunjungan rumah dan alih tangan kasus), 5) Dilaksanakan melalui format klasifikal kelompok dan individual, 6) Layanan Responsif, 7) Perencanan Individual, 8) Dukungan Sistem.

(Naskah Akademik ABKIN 2007)

\section{Bidang Layanan Bimbingan Konseling}

Pengembangan kehidupan pribadi, yaitu bidang pelayanan yang membantu peserta didik dalam memahami, menilai dan mengembangkan potensi dan kecakapan, bakat dan minat, serta kondisi sesuai dengan karakteristik kepribadian dan kebutuhan dirinya secara realistik. Bidang tersebut adalah bidang pelayanan yang membantu peserta didik dalam memahami dan menilai serta mengembangkan kemampuan hubungan sosial yang sehat dan efektif dengan teman sebaya, anggota keluarga, dan warga lingkungan sosial yang lebih luas. Pengembangan kemampuan belajar dalam rangka mengikuti pendidikan sekolah/madrasah dan belajar secara mandiri.

Pengembangan karir, yaitu bidang pelayanan yang membantu peserta didik dalam memahami dan meniali informasi, serta memilih dan mengambil keputusan karir.

Berdasarkan kajian literatur, layanan bimbingan dan konseling di sekolah harus dapat dilaksanakan. Penyuluh atau konselor bimbingan dan konseling haruslah memahami fungsi, prinsip, dan asas bimbingan dan konseling, serta ruang lingkup atau layanan apa saja yang harus diberikan oleh seorang konselor terhadap anak didiknya. Jika seorang konselor sudah memahami yang tersebut di atas, mereka juga harus memahami setting di mana layanan dan bimbingan itu diberikan. Posisi setting layanan dapat dilihat pada gambar berikut:

\section{PENEgASAN SETTING LAYANAN}

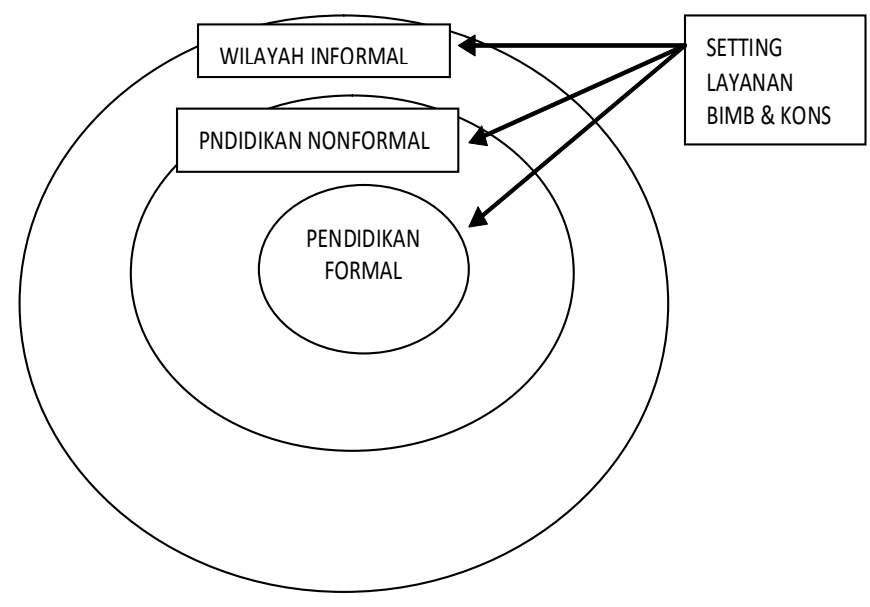

Selanjutnya, seorang konselor harus dapat melaksanakan fungsinya dengan baik di sekolah. Di DKI Jakarta, Jumlah guru bimbingan dan konseling khususnya di SMP Negeri rata-rata memiliki 3 orang guru bimbingan dan konseling, sehingga jumlah keseluruhan guru bimbingan dan 
konseling di SMP kurang lebih 864 orang. Jumlah tersebut tentu saja belum memadai karena jumlah rata-rata siswa di setiap sekolah kurang lebih 700 sampai dengan 1200 siswa persekolah. Hal ini tidak sesuai dengan Peraturan Pemerintah nomor 74 tahun 2008 bahwa beban kerja guru bimbingan dan konseling atau konselor, yang memperoleh tunjangan profesi dan masalah tambahan adalah, pengampu bimbingan dan konseling paling sedikit 150 peserta didik/tahun pada satu atau lebih satuan pendidikan.

Yang dimaksud pengampu layanan bimbingan \& konseling adalah, pemberi perhatian, pengarahan, pengendalian dan pengawasan kepada sekurang-kurangnya 150 peserta didik yang dapat dilaksanakan dalam bentuk pelayanan tatap muka terjadwal di kelas dan layanan perseorangan atau kelompok bagi yang dianggap perlu dan memerlukan.

Di samping itu, kebanyakan dari guru bimbingan dan konseling memiliki pengalaman kerja rata-rata lebih dari 20 tahun. Sehingga guruguru bimbingan dan konseling tersebut sulit untuk menguasai bidang (TIK) teknologi informasi komputer. Kurangnya pengetahuan guru bimbingan dan konseling tersebut akan mempengaruhi kualitas bimbimgan dan layanan yang mereka berikan. Hal itu ditegaskan dalam UndangUndang Nomor 20 Tahun 2003 Pasal 1 ayat 6 tentang adanya jabatan konselor. Maka untuk menjadi layanan professional Bimbingan dan Konseling, seorang konselor harus memiliki pengetahuan tentang filosofi, psikologi, sosial dan budaya, ilmu pengetahuan dan teknologi, pedagogis, religi dan teknologi.

Selanjutnya, faktor lain yang dapat mempengaruhi rendahnya mutu layanan bimbingan dan konseling di sekolah adalah banyaknya guru bimbingan dan konseling yang masih bertugas rangkat. Padahal, tugas dan fungsi guru bimbingan dan konseling sudah sangat banyak karena masih kurangnya jumlah guru yang seyogyanya berbanding 1:150 siswa.

Tidak kalah penting lagi, latar belakang pendidikan guru bimbingan dan konseling belum semuanya $\mathbf{S} 1$, hal ini menjadi salah satu penyebab rendahnya mutu layanan bimbingan seiring dengan rendahnya pengetahuan konselor tersebut tentang bidangnya.

Dinas Pendidikan memberikan fasilitas dan ruang gerak lebih luas dan memberikan otonomi kepada guru Bimbingan dan Konseling yang merupakan satu layanan sistem persekolahan.

\section{Simpulan dan Saran Simpulan}

Dari uraian di atas, dapat disimpulkan bahwa rendahnya mutu layanan bimbingan dan konseling di sekolah disebabkan oleh beberapa faktor yaitu: 1) Jumlah guru bimbingan dan konseling di masing-masing sekolah SMP di DKI belum sesuai dengan rasio 1:150 siswa; 2) Guru bimbingan dan konseling belum sepenuhnya menguasai dan memiliki kompetensi sebagai konselor; 3) Guru bimbingan dan konseling umumnya belum menguasai pengetahuan yang harus dimiliki oleh seorang konselor yang sesuai dengan Undang-Undang Nomor 20 tahun 2003 Pasal 1 ayat (6); dan 4) Guru bimbingan dan konseling masih bertugas rangkap

\section{Saran}

Untuk mengatasi permasalahan di atas, disarakan agar dinas pendidikan: 1) memberikan fasilitas dan ruang gerak lebih luas dan memberikan otonomi kepada guru bimbingan dan konseling. Di samping itu, pelatihan dan pembinaan terhadap guru bimbingan dan konseling akan diberikan secara maksimal sehingga dapat meningkatkan pengetahuan guru tersebut. Selanjutnya, penambahan dan pemberdayaan guru bimbingan dan konseling akan selalu dilakukan secara bertahap; 2) merealisasikan PP Nomor 74 tahun 2008 tentang rasio guru bimbingan dan konseling. Selanjutnya bagi guru bimbingan dan konseling agar lebih kreatif dan inovatif dalam mencari dan menggali pengetahuan baru yang berhubungan dengan bidangnya. Kemudian bagi peserta didik, harus dapat memanfaatkan fasilitas bimbingan dan konseling yang ada di sekolah masing-masing. 


\section{Pustaka Acuan}

Asosiasi Bimbingan dan Konseling Indonesia. 2007. Penataan Pendidikan Profesional Konselor. Naskah Akademik ABKIN

Menteri Pendidikan Nasional. 2006. Peraturan Menteri Nomor 22 tentang Standar Isi untuk Satuan Pendidikan Dasar dan Menengah. Jakarta: Departemen Pendidikan Nasional

Peraturan Pemerintah Nomor 74 Tahun 2008 tentang Rasio Guru Bimbingan Dan Konseling

Prayitno. Pedoman Khusus Bimbingan dan Konseling. Jakarta: Direktorat Jenderal Pendidikan Dasar dan Menengah, departemen Pendidikan Nasional, 2004

Undang-Undang Republik Indonesia Nomor 20 Tahun 2003 tentang Sistem Pendidikan Nasional 